\title{
Study of Genetic Variability, Path Analysis and Diversity of Selected Germplasm Lines of Wheat (Triticum aestivum L.), Under Very Late Sown Condition
}

\author{
Thakur P. ${ }^{*}$, Upadhyay P, Rashmi K., Namrata, Prasad R., Chandra K., Madhukar K. and Prasad L. C.
}

Dept. of Genetics and Plant Breeding, Institute of Agricultural Sciences, Banaras Hindu University, Varanasi, U.P. (221 005), India

\section{Corresponding Author}

Thakur P.

e-mail: padma.13291@gmail.com

\section{Article History}

Article ID: 3 C0972

Received in 03 ${ }^{\text {rd }}$ November, 2017

Received in revised form $20^{\text {th }}$ December, 2017

Accepted in final form $27^{\text {th }}$ March, 2018

\begin{abstract}
Fourteen diverse genotypes of wheat including three standard check variety were evaluated under heat stress condition during rabi season 2016-17 at Agriculture Farm, Institute of Agricultural Sciences, Banaras Hindu University. Genotypes were studied for genetic variability, path analysis and diversity with the aim to identify the superior genotype with significantly satisfactory yield under very late sown condition. The data were recorded for traits viz., days to heading, days to maturity, plant height, 1000 grain weight, grain yield plot ${ }^{-1}$ and biological

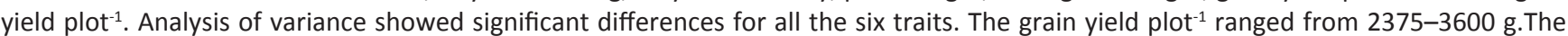
phenotypic coefficient of variation and genotypic coefficient of variation was observed highest for grain yield plot ${ }^{-1}$. Highest broad sense heritability was observed for 1000 grain weight while genetic advance was estimated to be highest for grain yield plot ${ }^{-1}$. Diversity analysis indicates that total 14 genotypes were grouped into 5 clusters. The highest inter-cluster distance was found between cluster IV and V followed by II and V. This exhibited that genotypes included in these clusters possess wide genetic diversity. Diversity study shows that the selection of genotypes for crosses from cluster V (WR544(C)) with cluster IV(PBW778), cluster II (HD3272) and cluster I (HI11621, WH1232, PBW757, DBW251, DBW250, HD3271 and WH1233) could give maximum heterosis and prove to be good recombinants. Hence, genotypes from such diverse groups can be selected for making the crosses and selection of desirable genotype for heat tolerance and better yield.
\end{abstract}

Keywords: Wheat, variability, correlation, diversity, path analysis

\section{Introduction}

Wheat (Triticum aestivum L.) accounts to second most grown crop in India after rice (Oryza sativa L.). In India, it is cultivated in an area of 30 mha acreage with the production of $97.44 \mathrm{mt}$ of wheat grains with productivity of $31.72 \mathrm{q} \mathrm{ha}^{-1}$ (IIWBR, 2017). It is the staple food for about $40 \%$ of the world's population and India's population is growing at the rate of $1.2 \%$ hence, it's indeed a challenging task for the plant breeders to increase the productivity and the overall production of various crops particularly of the staple crops so as to cope up with the growing demand of the food in the country and to achieve food security. The area under production cannot be increased hence, increase in production by use of superior varieties, hybrids, resources management, biotic and abiotic stress management are the available best options. A plant breeder or researcher is constantly concerned for improvement of the available genotypes in their yield potential either directly or indirectly. Varieties with the narrow genetic base are susceptible to abiotic and biotic stresses which despite their good yield potential causes a decrease in yield. Reduction in the genetic variability makes the crops increasingly vulnerable to diseases and adverse climatic changes (Aremu, 2012). Therefore, the breeding programme requires such methodologies so that it incorporates the desirable changes either through selection or through hybridization programme to develop superior genotypes. Based on requirement of the breeder, information on nature and magnitude of genetic variability, divergence and direct and indirect effect on yield by its component traits is important to plan the systematic breeding programme. The precise knowledge about Germplasm, variability and genetic relationship among breeding materials is a pre requisite for crop improvement programs as it helps in the development of desirable genotypes (Rauf et al., 2012). Considering the above facts, a study on 14 genotypes of different genetic background has been made, seeds were sown under very late condition (January 11, 2017) to determine its genetic variability, heritability, genetic advance, $D^{2}$ analysis for divergence and path analysis for yield and its component traits with main aim to identify potential genotypes to be used under breeding programme for crop improvement.

\section{Materials and Methods}

The experiment was conducted in the rabi season 2016-17 at 
Agriculture Research Farm, Institute of Agricultural Sciences, Banaras Hindu University, Varanasi, India. The experimental materials/ data for present study were taken from very SPLVLS-TAS-NWPZ/NEPZ programme/trials. Fourteen genotypes including three checks were planted in a plot size of $6.0 \times 1.80$ $\mathrm{m}^{2}$ in a Random block design with four replications. The experimental materials were sown on $11^{\text {th }}$ January, 2017, in very late sown condition. The recommended agronomic practices were followed to raise the good crops. Ten random plants were selected on which the observations were taken in each genotype in each replication for six quantitative traits viz., Days to Heading (DH), Days to Maturity (DM), Plant Height (HT), 1000 Grain Weight (GW), Grain Yield plot ${ }^{-1}(\mathrm{GY})$ and Biological yield plot $^{-1}$ (BY) as well as for three qualitative traits like thresh ability, texture, and colour of the grain. Qualitative traits were excluded from statistical analysis. Analysis of variance was computed on the basis of the model proposed by Panse and Sukhatme (1969). Phenotypic and genotypic coefficient (PCV and GCV) of variation were calculated as suggested by Searle (1961). Heritability in broad sense $h^{2}$ and genetic advance were estimated by the formula given by Allard (1960). D $D^{2}$ statistical analysis as given by Mahalanobis (1936) was used for estimation of genetic divergence among 14 genotypes. The clustering of $D^{2}$ values was formed by using the Tocher's method. Path coefficient analysis was obtained as given by Deway and Lu (1959). INDOSTAT software has been used for the statistical analysis of the recorded data for the 14 wheat genotypes.

\section{Results and Discussion}

\subsection{Genetic variability}

Analysis of variance (ANOVA) showed significant variation among the genotypes for all the traits under study (Table 1). Hence, it shows the presence of considerable variability among the genotypes providing the effective selection opportunity and sufficient scope for trait improvement. The range of yield

Table 1: ANOVA for six quantitative traits

\begin{tabular}{|c|c|c|c|c|c|c|c|}
\hline \multirow[t]{2}{*}{ S.V. } & \multirow[t]{2}{*}{ DF } & \multicolumn{6}{|c|}{ Mean square } \\
\hline & & $\mathrm{DH}$ & DM & $\mathrm{HT}$ & GW & GY (g) & BY \\
\hline Replication & 3 & $2.035^{*}$ & 0.273 & 0.154 & 0.098 & $1192560.000^{* * *}$ & $4.598^{*}$ \\
\hline Treatment & 13 & $161.670^{* * *}$ & $132.747^{* * *}$ & $108.153^{* * *}$ & $39.198^{* * *}$ & $702376.373^{* * *}$ & $2.580^{*}$ \\
\hline Error & 39 & 0.445 & 0.376 & 0.270 & 0.042 & 144867.216 & 1.266 \\
\hline
\end{tabular}

$*, * * *=$ significance at $(p=0.05)$, and $(p=0.001)$

was found $2375-3600 \mathrm{~g} \mathrm{plot}^{-1}$. The extent of genetic variability could be due to breeding materials belonging to different climatic zones of India. Similar results were also observed by Dutamo et al. (2015) in their experiment. Bhushan et al., 2013 observed that highest estimated value was for biological yield followed by plant height and grain yield while, spikelets per spike $^{-1}$ was lowest.The various parameters considered in the present study are presented in (Table 2). The magnitude of the genotypic coefficient of variation (GCV) was lower than phenotypic coefficient of variation (PCV) for all the traits under study indicating the role of environmental interaction in the expression of the characters. Burton and Devane (1953) classified PCV and GCV values as high (>20\%), medium (10$20 \%)$ and low (<10\%). The results obtained showed the highest GCV and PCV for grain yield plant ${ }^{-1}(12.57 \%, 17.95 \%)$ followed by Days to heading $(10.86 \%, 10.92 \%)$. Similar results has been reported by Bhushan et al., 2013; Kumar et al., 2013; Arya et al., 2017 respectively. Biological yield per plot, however, showed a wide difference between GCV and PCV (4.90\%, $10.80 \%$ ) with respect to other traits under study hence, indicating the high environmental effect on expression of the biological yield. Days to maturity, Plant height and 1000-Grain

Table 2: Estimate of genetic parameters for 6 quantitative traits of 14 genotypes

\begin{tabular}{|c|c|c|c|c|c|c|}
\hline Components & $\mathrm{DH}$ & DM & HT & GW & GY & BY \\
\hline GCV (\%) & 10.866 & 6.351 & 5.803 & 10.074 & 12.572 & 4.903 \\
\hline PCV (\%) & 10.926 & 6.387 & 5.832 & 10.096 & 17.953 & 10.801 \\
\hline $\mathrm{H}^{2}$ (Broad sense) \% & 98.9 & 98.9 & 99.0 & 99.6 & 49.0 & 20.6 \\
\hline Genetic adv. 5\% & 13.007 & 11.784 & 10.645 & 6.431 & 538.534 & 0.536 \\
\hline Genetic Adv. 1\% & 16.669 & 15.101 & 13.642 & 8.242 & 690.160 & 0.687 \\
\hline GenAdv (Mean 5\%) & 22.261 & 13.010 & 11.894 & 20.708 & 18.135 & 4.584 \\
\hline GenAdv (Mean 1\%) & 28.528 & 16.673 & 15.243 & 26.538 & 23.241 & 5.875 \\
\hline General mean & 58.429 & 90.571 & 89.500 & 31.057 & 2969.643 & 11.693 \\
\hline
\end{tabular}


Weight showed the least difference between PCV and GCV (Table 2) indicating that these traits are less influenced by the environment. Days to maturity (6.35\%, 6.38\%), and Plant Height $(5.80 \%, 5.83 \%)$ showed low values of GCV and PCV indicating low variability among different genotypes under study hence, selection for these traits will not be effective. In case of Jamil et al., 2017. The estimates PCV and GCV were high for grain yield plant ${ }^{-1}$ and 1000 -grain yield which is in agreement of the present study.

Broad-sense heritability is the variability inherited from parents to off spring. Robinson et al. (1949) classified heritability values as High (>60\%), Moderate (30-60\%) and Low (0-30\%). Heritability estimated in the present study was observed to be highest in 1000 grain weight followed by plant height, days to maturity and days to heading it was moderate for grain yield plot ${ }^{-1}$ and lowest in biological yield plot ${ }^{-1}$ (Table 2). High heritability shows the presence of additive gene effect and selection may be fruitful for crop improvement of these traits and low heritability indicates the high environmental effect on expression of the trait hence, selection on the basis of such traits for genetic improvement will not be effective. The estimate of heritability along with genetic advance is more useful to understand the type of gene action involved in the expression of various polygenic characters. Falconer and Mackay (1996) classified genetic advance as Low (0-10\%), Moderate (10-20\%) and high (>20\%). High heritability along with high genetic advance as percent mean (at 5\% and 1\%) were observed in days to heading and 1000 grain weight. Similar results also published by Nukasani et al., 2013; Jamil et al., 2017. Highest heritability estimates were observed for plant height (98.27\%) and highest genetic advance was reported for grain yield (83.22\%) by Jamil et al., 2017. Such results show the substantial contribution of additive gene action in the expression of the traits. Hence, direct selection for such characters would be more effective. 1000 grain weight showed high heritability along with low genetic advance showing predominance of non- additive gene action hence; direct selection for such traits would be misleading. Grain yield plot $^{-1}$ exhibited low heritability and high genetic advance, similarly biological yield plot $^{-1}$ has low heritability and high genetic advance. High heritability of desirable traits indicate much more contribution/expression of gene(s) and less influence of environment hence, priority should be given to select the high heritable traits under breeding programme.

\subsection{Genetic diversity}

Based on $D^{2}$-statistics the fourteen wheat genotypes were grouped into five clusters presented in Table 3 and Figure 1. Of them cluster I has the maximum number genotypes (7) followed by cluster III (4) while, cluster II, IV and V had only one genotype each. The inter-cluster distance was observed to be higher than intra-cluster distance, suggesting wide genetic diversity among clusters (Table 4). The inter-cluster distance varied from 110.03 to 1099.02 . The highest intercluster distance was observed between cluster IV and V
Table 3: Inter and intra (Diagonal) cluster distances for five clusters

\begin{tabular}{cccccc}
\hline & $\begin{array}{c}\text { Clus- } \\
\text { ter 1 }\end{array}$ & $\begin{array}{c}\text { Cluster } \\
2\end{array}$ & $\begin{array}{c}\text { Cluster } \\
3\end{array}$ & $\begin{array}{c}\text { Cluster } \\
4\end{array}$ & $\begin{array}{c}\text { Clus- } \\
\text { ter5 }\end{array}$ \\
\hline Cluster 1 & 96.07 & 2264.39 & 3314.83 & 4173.92 & 5834.87 \\
Cluster 2 & 264.39 & 0.00 & 381.85 & 110.30 & 961.20 \\
Cluster 3 & 314.83 & 381.85 & 114.31 & 418.70 & 261.08 \\
Cluster 4 & 173.92 & 110.30 & 418.70 & 0.00 & 1099.02 \\
Cluster 5 & 834.87 & 961.20 & 261.08 & 1099.02 & 0.00 \\
\hline
\end{tabular}

Clustering by tocher method

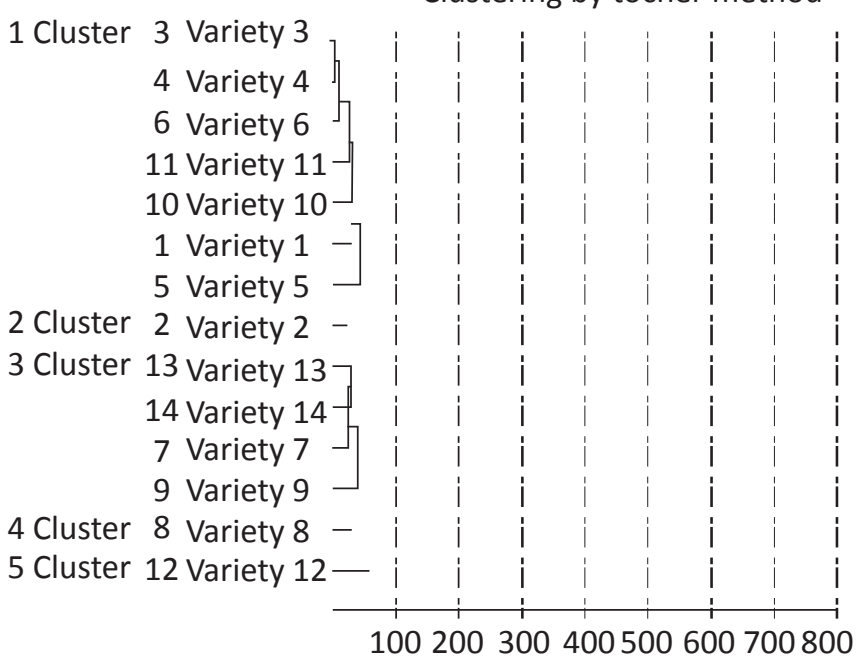

Figure 1: Clustering of 14 wheat genotypes by tocher method

Table 4: Cluster means by Tocher method for 6 traits under study

\begin{tabular}{ccccccl}
\hline & $\begin{array}{c}\text { Char. } \\
1\end{array}$ & $\begin{array}{c}\text { Char. } \\
2\end{array}$ & $\begin{array}{c}\text { Char. } \\
3\end{array}$ & $\begin{array}{c}\text { Char. } \\
4\end{array}$ & Char. 5 & $\begin{array}{l}\text { Char. } \\
6\end{array}$ \\
\hline Cluster 1 & 60.14 & 92.71 & 92.00 & 28.82 & 2810.71 & 11.66 \\
Cluster 2 & 63.00 & 91.00 & 79.00 & 29.68 & 2450.00 & 10.93 \\
Cluster 3 & 56.25 & 86.50 & 89.00 & 34.14 & 3362.50 & 11.96 \\
Cluster 4 & 67.00 & 100.00 & 87.00 & 29.84 & 2425.00 & 10.80 \\
Cluster 5 & 42.00 & 82.00 & 87.00 & 37.00 & 3575.00 & 12.50 \\
\hline
\end{tabular}

(1099.02) showing high diversity between them. However, minimum distance was observed between cluster IV and II (110.03), indicating close relationship between these clusters hence selection would not be effective. They may produce desirable transgressive segregants which may be further useful in the breeding programme. Similar results has been reported by Mundiyara et al., 2013, they studied Genetic divergence using $D^{2}$ Analysis of 49 genotypes of wheat and the genotypes were grouped into 8 clusters. The highest intra-cluster distance was observed in cluster III (114.31), followed by cluster I (96.07) while, the cluster II. IV and V had only one genotype. Divergence study shows that the 
genotypes of cluster V (WR544(C) with cluster IV( PBW778), cluster II (HD3272) and cluster I (HI11621, WH1232, PBW757, DBW251, DBW250, HD3271, WH1233) and cluster V and may give maximum heterosis and prove to be good recombinants and attain maximum genetic advance and can be utilized in improvement programme

The cluster means analyzed for 6 quantitative traits presented in Table 5, the results shows that Cluster IV exhibited highest mean value for days to heading (67.00) and days to maturity (100.0). Cluster I showed the highest mean for plant height (92.00) while, cluster $V$ exhibited highest mean for 1000 -grain weight (37.00), grain yield plant ${ }^{-1}(3575.00)$ and biological yield plot $^{-1}$ (12.50). On the basis of degree of diversity and cluster mean value it may be suggested that maximum heterosis and good recombinants could be obtained in crosses between genotypes of these diverse clusters for crop improvement. The contribution of individual trait was highest in 1000 grain weight $(46.15 \%)$ followed by plant height (26.37\%), days to maturity (18.68\%), days to heading (7.9\%). Thus, 1000 grain weight is the highest contributors of genetic divergence. Similar result have been reported by Dutamo et al., 2015.

\begin{tabular}{ll}
\hline \multicolumn{2}{l}{ Table 5: List of genotypes belongs to different clusters } \\
\hline Groups & Name of genotypes \\
\hline Cluster 1 & HI11621, WH1232, PBW757, DBW251, \\
& DBW250, HD3271, WH1233 \\
Cluster 2 & HD3272 \\
Cluster 3 & DBW14(C), DBW71(C), PBW777, DBW249 \\
Cluster 4 & PBW778 \\
Cluster 5 & WR544(C) \\
\hline
\end{tabular}

\subsection{Path analysis}

Correlation coefficients at phenotypic and genotypic levels are presented in the Table 6 . Significant $(p<0.01)$ and positive correlations were observed between days to heading and days to maturity both at phenotypic and genotypic levels. A significant $(p<0.01)$ and negative correlation was observed between days to heading and 1000 grain weight and also between days to heading and grain yield both at genotypic and phenotypic level. Days to heading showed significant $(p<0.01)$ and negative correlation with biological yield at genotypic level and phenotypic level $(p<0.05)$. Days to maturity showed significant and negative correlation with 1000 grain weight and grain yield both at genotypic and phenotypic level while with biological yield it showed negative and significant $(p<0.01)$ at genotypic level and significant $(p<0.05)$ at phenotypic level. Plant height showed positive and significant $(p<0.05)$ correlation with grain yield and biological yield at the genotypic level only. 1000 grain weight showed positive and significant correlation with grain yield both at phenotypic and genotypic level whereas, with biological yield it showed significant $(p<0.01)$ and positive correlation at the genotypic level and significant $(p<0.05)$ and positive at the phenotypic level. Grain yield showed positive and significant correlation with biological yield per plot both at phenotypic and genotypic level. Plant height showed no significant correlation with traits except grain yield and biological yield significant only at genotypic level. Findings of the present study are in agreement with the reports of Khan and Dar, 2009; Fellahi et al., 2013; Singh et al., 2017. The highest correlation coefficient was observed between 1000 grain weight and yield followed by grain yield with biological yield. The lowest correlation coefficient was observed between plant height and days to

\begin{tabular}{|c|c|c|c|c|c|c|c|}
\hline Traits & raits & $\mathrm{DH}$ & DM & HT & GW & GY & BY \\
\hline \multirow[t]{2}{*}{$\mathrm{DH}$} & $\overrightarrow{\mathrm{G}}$ & 1.0000 & $0.8080^{* * *}$ & 0.1554 & $-0.6426^{* * *}$ & $-0.7137^{* * *}$ & $-0.6988^{* * *}$ \\
\hline & $P$ & 1.0000 & $0.7987^{* * *}$ & 0.1573 & $-0.6367^{* * *}$ & $-0.4905^{* * *}$ & $-0.2981^{*}$ \\
\hline \multirow[t]{2}{*}{ DM } & G & & 1.0000 & 0.2085 & $-0.6254^{* * *}$ & $-0.6339^{* * *}$ & $-0.6658^{* * *}$ \\
\hline & $P$ & & 1.0000 & 0.2066 & $-0.6208^{* * *}$ & $-0.4323^{* * *}$ & $-0.3047^{*}$ \\
\hline \multirow[t]{2}{*}{ HT } & $\mathrm{G}$ & & & 1.0000 & -0.0871 & $0.2264^{*}$ & $0.3342^{*}$ \\
\hline & $P$ & & & 1.0000 & -0.0856 & 0.1447 & 0.1458 \\
\hline \multirow[t]{2}{*}{ GW } & $\mathrm{G}$ & & & & 1.0000 & $0.9235^{* * *}$ & $0.6168^{* * *}$ \\
\hline & $P$ & & & & 1.0000 & $0.6391^{* * *}$ & $0.2714^{*}$ \\
\hline \multirow[t]{2}{*}{ GY } & G & & & & & 1.0000 & $0.8768^{* * *}$ \\
\hline & $P$ & & & & & 1.000 & $0.6609^{* * *}$ \\
\hline \multirow[t]{2}{*}{ BY } & G & & & & & & 1.0000 \\
\hline & P & & & & & & 1.0000 \\
\hline
\end{tabular}

$*, * *, * * *=$ significance at $(p=0.05),(p=0.01)$ and $(p=0.001)$ 
heading followed by plant height and days to maturity. The highest negative correlation coefficient was between grain yield followed by days to heading and biological yield.

\subsection{Path coefficient analysis}

Path coefficient analysis was carried out using coefficient of all the traits with grain yield per plant presented in Table 7 and Figure 2. Path analysis separates the direct effects from the indirect effects through other related characters by partitioning the correlation coefficient (Dixet and Dubey, 1984). In the present study maximum direct effect on grain yield per plant was contributed by 1000 grain weight (0.6927), followed by biological yield plot $^{-1}(0.4253)$. On the other hand, negative and direct effect was contributed by days to heading $(-0.1044)$ only. Days to maturity $(0.1394)$ and plant height $(0.1318)$ showed low and positive direct effect on

Table 7: Path coefficient analysis showing direct (bold and diagonal) and indirect effect of different traits

\begin{tabular}{lcccccc}
\hline $\begin{array}{l}\text { Traits } \\
\text { Traits }\end{array}$ & DH & DM & HT & GW & GY & BY \\
\hline DH & -0.1044 & -0.0844 & -0.0162 & 0.0671 & 0.0730 & -0.7137 \\
DM & 0.1126 & 0.1394 & 0.0291 & -0.0871 & -0.0928 & -0.6339 \\
HT & 0.0205 & 0.0275 & 0.1318 & -0.0115 & 0.0440 & 0.2264 \\
GW & -0.4451 & -0.4332 & -0.0604 & 0.6927 & 0.4272 & 0.9235 \\
BY & -0.2972 & -0.2832 & 0.1422 & 0.2623 & 0.4253 & 0.8768 \\
\hline
\end{tabular}

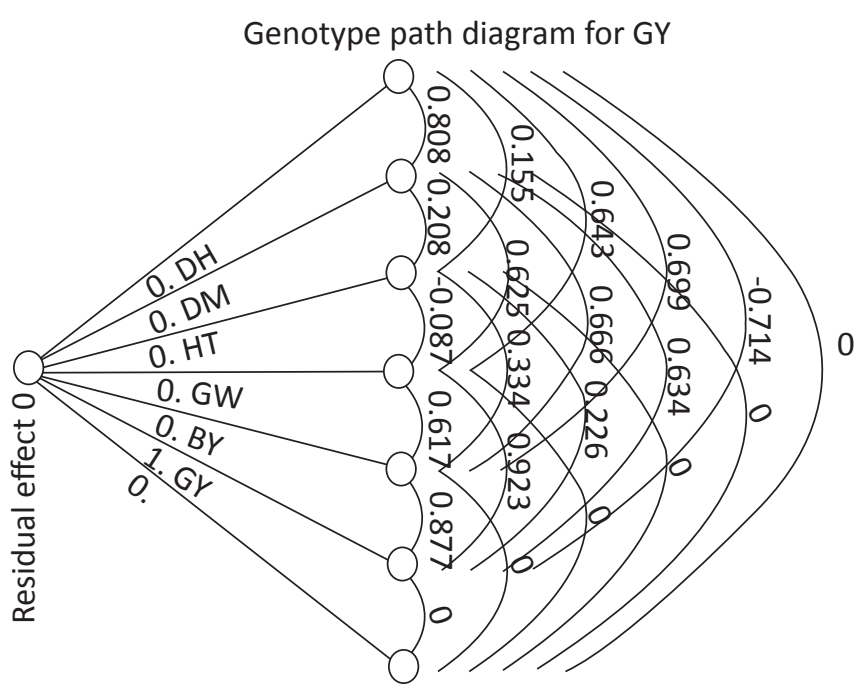

Figure 2: Path diagram showing direct and indirect effect of various traits on grain yield/ plant

grain yield per plant. 1000 grain weight recorded a highest positive indirect effect via biological yield per plot $(0.4272)$ and highest negative effect was shown by days to maturity via biological yield $(-0.0928)$ and highest indirect positive effect was shown by biological yield via 1000 grain weight and highest negative indirect effect by 1000 grain weight via days to heading $(-0.4451)$ on the grain yield per plant. Similar findings has been reported by Naik et al., 2016; Singh et al., 2017; Khan and Dar, 2009.

\section{Conclusion}

Assessment of genetic variability, diversity and path analysis revealed that the wheat germplasm possess good amount of genetic variability for all the traits under study. High variable genotype placed in diverse cluster and traits showing significant direct and indirect effect on grain yield can be selected for making crosses as per the requiremrent of the breeder that would give maximum heterosis and prove to be good recombinants.

\section{References}

Allard, R.W., 1960. Principle of plant breeding. John Wiley and sons, New York, 185.

Aremu, O., 2012. Exploring statistical tools in measuring genetic diversity for crop improvement, genetic diversity in plants, Prof. Mahmut Caliskan (Ed.), ISBN: 978-95351-0185-7.

Arya, V.K., Singh, J., Kumar, L., Kumar, R., Kumar, P., Chand, P., 2017. Genetic variability and diversity analysis for yield and its components in wheat (Triticum aestivum L.). Indian Journal of Agriultural Research 51(2), 128-134.

Bhushan, B., Bharti.S., Ojha, A., Pandey, M., Gourav, S.S., Tyagi, B.S., Singh G., 2013. Genetic variability, correlation coefficient and path analysis of some quantitative traits in bread wheat. Journal of Wheat Research 5(1), 24-29.

Burton, G.W., DeVane, E.H., 1953. Estimating heritability in tall fescue (Festuca arundinacea) from replicated clonal material. Agronomy Journal 45, 478-481.

Dewey, D.R., Lu, K.H., 1959. A Correlation and path coefficient analysis of component of crested wheat grass seed production. Agronomy Journal 51, 515-518.

Dixet, P., Dubey, D.K., 1984. Path analysis in lentil (Lens culinaris Med.). Lens Newsletter 11, 15-17.

Dutamo, D., Alamerew, S., Eticha, F., Assefa, E., 2015. Genetic variability in bread wheat (Triticum aestivum L.) germplasm for yield and yield component traits. Journal of Biology, Agriculture and Healthcare 17(5), 140-147.

Falconer, D.S., Mackay, T.F.C., 1996. Introduction to quantitative genetics. ( $4^{\text {th }}$ Eds.), Longman, Essex, England.

Fellahi, Z., Hannachi, A., Bouzerzour, H, Boutekrabt, A., 2013. Correlation between traits and path analysis coefficient for grain yield and other quantitative traits in bread wheat under semi-arid conditions. Journal of Agriculture and Sustainability 3(1), 16-26.

Indian Institute of Wheat and Barley Research (IIWBR), 2017. AICRP-W and B, Progress Report, Crop Improvement.

Jamil, A., Khan, S., Sayal, O.U., Waqas, M., Qudratullah, Ali, S., 2017. Genetic variability, broad sense heritability and genetic advance studies in bread wheat (Triticum aestivum L.) germplasm, Pure Applied Biology 6(2), 538-543. 
Khan, M.H., Dar, A.N., 2009. Correlation and path coefficient analysisof some quantitativetraits in wheat (Triticum aestivum L.). African Crop Science Journal 18(1), 9-14.

Kumar, B., Singh, C.M., Jaiswal, K.K., 2013. Genetic variability, association and diversity studies in bread wheat (Triticum aestivum L.), Bioscan 8(1), 143-147.

Mahalanobis, P.C., 1936. On the generalized distance in statistics. Proceedings of the National Institute of Science 2, 49-55.

Mundiyara, R., Kerkhi, S.A., Jakhar, M.L., Ram, G., 2013. D² analysis in bread wheat (Triticum aestivum L.). Journal of Plant Science and Research 29(2), 215-219.

Naik, V.R., Biradar, S.S., Hanchinal, R.R., Desai, S.A., Veeresha, B.A., 2016. Correlation and path analysis for yield and some morpho-physiological characters in tetraploid wheat under irrigated and rainfed conditions. Research Environment for Life Science 9(2), 206-208.

Nukasani, V., Potdukhe, N.R., Bharad, S., Deshmukh, S., Shinde, S.M., 2013. Genetic variability, correlation and path analysis in wheat. Journal of Wheat Research 5(2), 48-51.

Panse, V.G., Sukhatme, P.V., 1969. Statistical methods for agricultural workers. Indian Council of Agricultural Research, New Delhi.

Rauf, S., Tariq, S.A., Hassan, S.W., 2012. Estimation of pedigree based diversity in Pakistani wheat (Triticum aestvium L.) germplasm. Communications in Biometry and Crop Science 7(1), 14-22.

Robinson,H.F., Comstock, R.E., Harvey, P.H., 1949. Estimation of heritability and the degree of dominance in corn. Agronomy Journal, 41, 353-359.

Searle, S.R., 1961. Phenotypic, Genotypic and environmental correlations. Biometrics 47, 474-480.

Singh, O., Dwivedi, S.K., Shukla, R.S., Samaiya, R.K., Upadhayay, A., Vasht, D., Singh, M., Prajapati., 2017. Correlation Studies in diverse lines of Wheat (Triticum aestivum L.) under Restricted Irrigation.International Journal of Pure Applied Bioscience 5(1), 379-388. 